\title{
Relationship between Islamic Human Resource Management (IHRM) practices and trust: An empirical study
}

\author{
Nik Mutasim Nik Ab. Rahman ${ }^{1}$, Mohamad Adnan Alias ${ }^{1}$, Sharmin Shahid ${ }^{1}$, \\ Mohamad Abdul Hamid ${ }^{2}$, Syed Shah Alam² \\ ${ }^{1}$ Graduate School of Business, The National University of Malaysia (Malaysia) \\ ${ }^{2}$ Faculty of Economics and Management, The National University of Malaysia (Malaysia) \\ nmutasim@botmail.com,nan10@ukm.my, sharmin1229@yaboo.com, shahalam@uk.m.my
}

Received: March 2013

Accepted: August 2013

\section{Abstrad:}

Purpose The purpose of this study is to explore and examines the theoretical frameworks of Islamic human resource management practices and trust in organization. Additionally, to investigate the extent to which Islamic HRM practices inspire and revival employees trust in organization.

Design/methoddogy/approadr. This study comprised sample of 236 Islamic Bank employees in Bangladesh. A cross-sectional research design was used to examine the relationship between Islamic Human Resource Management practices and trust. Data were gathered based on personal administered questionnaire.

Findings: This study results show that knowledge, understanding and practices of Islamic principles, recruitment and selection, training and development, and reward system significantly related to the trust. But performance appraisal are found have insignificant relationship.

Research limitations/implications: The data for this study are collected by self-administered questionnaire, a method with well-known shortcomings. Second, this study concentrated on the Islamic bank employees in Bangladesh. 
Practical implications: An important implication of this research is that the interesting findings give some insight to the management of Islamic bank to focus on improving Islamic Human Resource Management practices, in their all kind of management, as that could improve their trust in the bank.

Originality/value The findings are original and unique and are based on the literature from different researches. The results are based on a sample of Islamic Bank employees in Bangladesh. The research findings are useful to academics and management of Islamic bank all over the world.

Keywords: Islamic Human Resource Management (IHRM), trust in organization, Islamic Banks, Bangladesh

\section{Introduction}

Islamic values are a set of beliefs and ethics, a social doctrine of all aspects of our existence, moral and physical, spiritual and intellectual, personal and communal of human life (Abbasi, Rehman \& Abbasi, 2010; Asad, 2007). According to Seidu (2006) Islamic values are equally significant with human being's need for prosperity and happiness in all affairs of life. Abbasi et al. (2010), noted Fiorina (2001) argued that in today's ethical crisis of all over the business world specify, we must affirm our promise to build organizations that aspire to Islamic perspective of human resource management (HRM). Consequently, the background of the study indicates that the relationship between religion and ethical behavior is an important factor to enhance business performance. Since, the challenging business environment creates undue competition among man, machine, and employee sustainability in the organization (Pfeffer, 2005). Islamic HRM practices are able to mitigate this competition by ensuring Islamic ethics, guidelines and principals in organization (Namazie \& Frame, 2007).

Islamic HRM suggests that employees are not just a servant, they are valuable assets, and they should be considered as a source of powerful and dynamic workforce assets (Beekun, 1997). Indeed, Islamic HRM practices emphases on the development of employee's individual skills, abilities, attitudes and job knowledge to contribute for accomplishing organizational objectives (Ali, 2005). Islamic HRM believes that individual to identify his or her strengths and make full use of them. The concept of Islamic HRM aims at understanding the needs and hopes of employees in a better way. Many researchers (e. g., Beekun, 1997; Ali, 2005; and Khan, Farooq \& Hussain, 2010) highlighted Islamic HRM practices and trust in the organization is one of the vital factors that associated with job satisfaction, high performance, and low turnover in workplace. In fact, trust in organization is most likely mutual exchange behavior among the employees in work place. Moreover, when trust levels are low, individuals tend to be less 
creative, less forthcoming with ideas and exert less effort towards organizational goals (Mishra \& Morrisey, 1990). Furthermore, without trust in organization, management may erroneously assume that employees need more rigid supervision and tighter controls. It seems that the significant of Islamic HRM might have an influence on the development of employee trust in organization by practicing Islamic guiding (Yousef, 2001).

It is now very noticeable, the success of Islamic organizations make people to realized that the application of 'Islamic' codes and conducts, and ethics and moral values have long been sustainability, and provide high productivity, good customer service, smooth managementemployee relationships over the competitive and challenging business environment. Moreover, to keep peace with this rapid growth it is require ensuring that Islamic HRM must be well tuned, properly implemented, and continuously monitored to accomplish desired organizational outcomes (Hashim, 2009). However, at present, Islamic HRM practices are rarely highlighted and very limited in the literature. One of the most significance and contributions of this study is that it fills the gap in Islamic HRM practices as well as the literature regarding relationships between Islamic HRM practices and employee trust in organization.

\section{Objective of the study}

The essential objectives of this study is to show the extent to which Islamic human resource management practices inspire and relevant toward revival employees trust in organization. Additionally, this study is to examine the relationship between Islamic HRM practices, and trust in organization based on Islamic principles.

\section{Literature review}

\subsection{Principles of Islamic HRM}

The values of an 'Islamic' organization are based on Al-Qur'an (The words of Allah) and Hadith (The words of Prophet Muhammad; Peace be upon Him). For Muslims, Islam is an institution quote from Al-Qur'an and the occurrence and experience of Prophet Muhammad's (PBUH) life to explain and clarify Islamic roots of their socio-economic policies and practices. Indeed, the Holy Qur'an and Hadith is the basis for the Shariah Principles (Islamic Law) and norms of humanity. Principally, the Shariah being an essential part of revelation is a guideline for human action covering every aspect of life. From the religious point of view, each and every Islamic organization must obey the Islamic law named Shariah principles and Islamic knowledge and understanding for their every aspects of working environment (Seidu, 2006).

While, Islamic organization is needed to fulfill all requirements of Shariah to maintain the relationships among organization and their stakeholders, top level management, suppliers, customers, and employees. The main purpose of Islamic HRM is to rigorously maintain and practices Islamic law in the relationships between management and employee with in the 
organizational phenomenon (Hashim, 2009). Indeed, Islamic HRM is significant to establish the Islamic way of managing employees' as well as a vital function that performed and facilitates, the most effective and efficient use of employees' to accomplish organizational goals (Tayeb, 1997).

\subsection{HRM practices and trust in organization}

HRM practices are defined as a process consisting of the acquisition, development, motivation, and maintenance of human resource (Lee \& Lee, 2007). In the complex business world the main task of HRM practices is to manage their employees smoothly, with the objectives of enhancing their psychological attachment to the organization (Zeffane \& Connell, 2003). Within the societal context trust in organization assumed to depend on employees' experience of their coworkers' actual behavior (Pucetaite, Lamsa \& Novelskaite, 2010). In this light, there is obviously a need to integrated trust into daily organizational processes and operations; in particular the HRM practices. Indeed, the levels of trust within an organization can influence the successful implementation of the HRM practices. Therefore, the effectiveness and success of the HRM policies and practices depend on employees' trust of the management in the organization (Whitener, 1997). At the same time, aspects of HRM practices such as training and development, promotion, compensation, job security, recruitment and selection, and performance evaluation have been shown to effect the development of trust in organization (Whitener, 2001).

In other words, trust in organization is 'lubrication' for the HRM practices (Williams, 2005). This is reduce friction and hence, operates the organization smoothly to accomplish higher levels of employees' job satisfaction, low absenteeism, and low turnover. While, trust plays a complex role in organization, it has been referred to as the 'emotional glue' that binds the management and organization to their employees. However, trust in organization is not a permanent fixture. It can be lost through one careless mistake by management (Cook, Cheshire \& Gerbasi, 2006). To generate and sustain trust, managers must conduct themselves behind closed doors just as they would if they were being observed and it is appropriately handled by the daily HRM practices (Hunt, Lara \& Hughey, 2009).

The role of trust in the development and maintenance of successful relationships is likely to be particular significance in the financial services sector because of the complexity and much complication situations of workplace (Dirks \& Ferrin, 2001). According to Ferres and Travaglione (2003), higher trust at each organizational level such as trust in organization, trust in immediate manager, and trust in co-workers positively related to transformational leadership and effective HRM practices. Trust signifies an exchange relationship by involves underling action and feelings of confidence in another. In the organizational environment trust belongs to quality of interpersonal relationship between trust in management, trust in coworker and trust in organization itself (Carnevale \& Wechsler, 1992). 


\subsection{Aspects of Islamic HRM practices}

Islamic law is unbiased, fair and justice in every activity of human beings, without discrimination, irrespective of status and position between other parties relationships. There are no any options for partial practices of Islamic law (Bukhari \& Muslim). Therefore, it is the prime duty and responsibility of management to have adequate knowledge and understanding regarding Islamic principles. In addition, with having Islamic knowledge they must buildup the entire HR systems and practices in their daily working life (Al-Faruqi \& Al-Bann, 1980).

Human resource management is an integrated strategy and planned development process for effective utilization of their employees' ability and effort to accomplish organizational goals and outcomes (Storey, 1995). According to Ali, Gibs and Camp (2000) \& Tayeb (1997), several HRM issues in organizations have their foundations in religion especially, Shariah Principles. Namazie and Frame (2007) have mentioned regarding five Islamic HRM practices i. e., selection and recruitment, training and development, career development, performance management, and reward system. Moreover, based on Al-Qur'an and Hadith; Hashim (2009) described that there are five Islamic HRM practices such as recruitment, selection, performance appraisal, training and development, and compensation are concerns on Islamic principles. Islamic management emphasizes on the principles of human well being, and fairness as well as justice of resource management. Indeed, the management if they concerned about the existence of organizational justice and harmonic employee relationships can't afford to ignore the potential contribution of aspects of Islamic HRM practices (Ali, 2005; Yousef, 2001).

\subsection{Relationships between Islamic HRM practices and trust in organization}

The literature review have found, significant relationship between aspects of Islamic HRM practices and employee trust in organization based on the holy Qur'an and Hadith. In the Qur'an (4: 58-59); Recruitment is stated that "Allah doth command you to render back your trust to those to whom they are due; and when ye judge between man and man, that ye judge with justice; verily how excellent is the teaching which He giveth you! For Allah is He who heareth and seeth all things. O ye who believe! Obey Allah and the Messenger, and those charged with authority among you. If ye differ in anything among yourselves, refer it to Allah and His Messenger if ye do believe in Allah and the Last Day: that is the best, and most suitable for final determination." Principally, the recruitment process must be done fairly and piously. It is also required in Islamic HRM practices that all recruitment decision must be made wisely, to ensure hired candidate is the best suited for this particular job. Moreover, Islam requires the person who is in charge of recruitment to be pious and just (Ahmad, 1995).

Selection is one of the most complicated tasks in any organization. The Qur'an states, (28:26): "said one of the (damsels): 'O my (dear) father! Engage him on wages; truly the best of men for thee to employ is the (man) who is strong and trust worthy." The Islamic selection practice 
aim to select pious workers who possess good personality or akhlak, sprit of team work or amal jama'i, experts (Surah al-Qasas: 26; Sunan al-Bukhari) in terms of qualifications, skills, experiences, health, intelligence, dedication and committed toward their tusk. The quality, excellent, and competent workers in Islamic HR practices that should be hired who qualified in terms of spiritual, personality or characters (akhlak), mental and physical (Azmi, 2008). In Islamic law, employee selection is abided by certain principles. Firstly, principle is justice; according to Syed Agil, Jasin and Pa'wan (2007), wrote from Ali Ibn Talib; "does not nominate them (officer) an account of favoritism or egoism. These two attributes reflect injustice and treachery." Secondly, an employee is selected based on his competency. The individual is not to be appointed based on kinship or blood relationship, friendship, wealth, age, race, and political power or alike. Finally, principle is honesty; both the applicant and recruiter have to be honest. Islam forbids assignment of work that will exceed the individual's capacity. Ali (2005) reported that the main factor affecting employees' selection in contemporary Muslim countries is friendship networks; "during his lifetime Prophet Muhammad (p.b.u.h) refused to accept the request of his close friend, Abu Zarr, who sought to work as a governor, and told him kindly that Abu Zarr was weak (not suitable for work), and the employment process is based on the values of trust and responsibility."

Performance appraisal is the process by which an employee's contribution to the organization during a specified period of time is assessed (Shaw, Delery \& Abdullah, 2003). In Islamic perspectives, employees' performance measurement should be based on justice and fairness and accountability and responsibility (Surah an-Nahl: 90; Surah al-A'raf: 85; Surah al-Hujuraat: 13). In order to ensure this to happen, appraisers should be sent for training (Surah an-Nisaa: 58). They also should bear in mind that their task is a trust from Allah (Swt.), and thus should not publicize their employees' weakness (Surah an-Nisaa: 149) and discriminate them on the basis of race, color and religion (Hashim, 2008). Moreover, there are two methods of performance evaluation; (a) judgment based: this approach normally use statements related to traits, attributes, and characters of employees i, e., employee decency, truthfulness, kindness, shouldering, responsibility, maturity, justness decisiveness, reliability, dedication, and so on; (b) behavioral evaluation: the attributes should also be based on the criteria included in the job selection i. e., honesty, and whether or not the employees perform the five pillars of Islam (Ali, 2005).

Training refers the process of increasing knowledge, skill, attitude, abilities, aptitude, and potentials of employee for better job performance and accomplishes the organizational goals (Flippo, 1984). Islamic training and development focuses on purifying one's soul (Tazkiyah al-nafs). The Qur'an encourages human being to acquire knowledge, skills and technology, and highly praises those who strive in order to earn a living. Indeed, man's basic qualification for being the representative of Allah on earth is to process knowledge. Mostly, training is the process of developing qualities in HR that will able them to be more knowledgeable, and skilled this enable them to be more productive. Allah said (58: 11); "are those who know equal to 
those who know not? But only they who are endowed with understanding keep this in mind." Therefore, Muslims are urged to seek knowledge from cradle to grave and it is their obligation to seek knowledge diligently as well as obtain excellence in performance to serve his/her employer as well (Hashim, 2008).

Through well establish compensation schemes employee well being will better improved and this is likely to influence their level of employee trust in organization (Perry, 2004). The management systems practiced by the early Muslims more concern on the importance of managing people and taking care of their need and problems. Managers should have that personal touch in order to achieve respect and trust of their subordinates. From, Ali Ibn Talib; he gave specific instructions to his officers; "be kind and affectionate to your subjects, observe Allah's right and people's right in own behavior and in that of your close relatives, your employees and those who have access to you. Otherwise you will not be fair; give them decent remuneration that will give the power to resist temptation!" Islamic perspectives compensation based on some principles such as, firstly, wages must be determined with mutual consultation and consent before they (worker) start work (Qur'an 28: 26-28); secondly, it should be proportional based on the amount of work done, capabilities, and competencies (Sunan Ahmed, Surah al-Yasin: 54; Surah an-Najm: 39); thirdly, the amount of salary should be fixed according to current market rate (Sunan Ahmed, Surah al-Syua'ra: 183); fourthly, The employees should be rewarded as soon as their work done and completed (Sunan Ibn Majah); finally, there is no discrimination in rewarding workers in an Islamic law no matter the gender of the worker is (Surah an-Nahl: 97; Surah al-Kahfi: 30; Surah al-A'raf: 85). Moreover, Islam strictly prohibits coercion and forced labor. According to Beekun (1997) if there is a situation of forced labor and wages is not adequate, individual worker may not feel motivated to give their best or satisfactory effort. While, a worker is entitled to receive a fair and just wage for his/her work (Ahmad, 1995).

\section{Conceptual framework and hypotheses development}

The conceptual framework of the study is design based on the previous literature review. Indeed, the study hypothesizes that effective design and implementation of Islamic HRM practices able to increase employees trust in their supervisor, work group, and organization. These in turn has a significant impact on organizational outcomes. The aspects of Islamic HRM practices include knowledge, understanding and practices of Islamic principles, recruitment and selection, performance appraisal, training and development, and reward system based on Islamic principles (refer Figure 1).

The Hadith says, 'a good servant is he who possesses determination and honesty; and he who servant is he who devoid of honesty do not possess faith. Indeed, Islamic ideas emphasize on superior trust, honesty and reliability concerning overall behavior. In fact, for practicing Islamic values it is obvious to have a rigorous understanding of the basic Islamic principles, ideology, 
guidance, and strictly follow up everyday in one's both personal and working life as explained in the Qur'an and Hadith. Consequently, organization should have knowledge that a pious Muslim is proficient or efficient to his/her task and feel high trust in organization. Consistent with this literature, this study propose the following hypotheses:

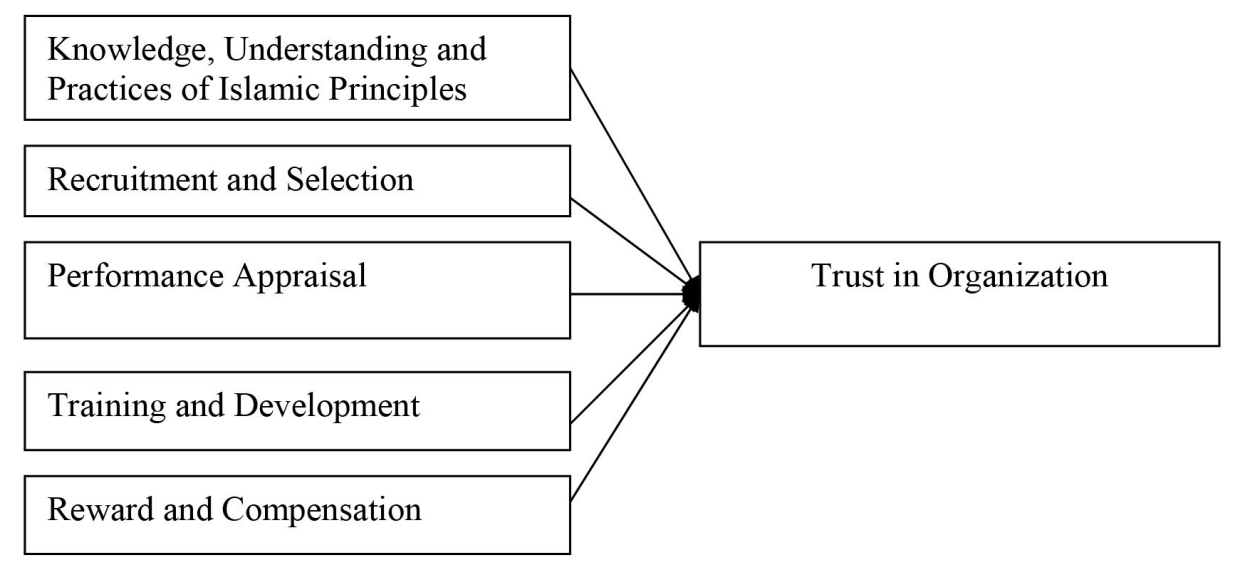

Figure 1. Conceptual Framework

Hypothesis 1: Rigorous knowledge and understanding of Islamic HRM principles would increase employees' trust in organization.

Recruitment and selection of new employees is the vital step for Islamic HRM practices. Organization should ensure that recruitment and selection process is completed by guideline prescribes in Qur'an and Hadith and following with full of 'amanah'. The employers are required to inform the truth and facts about the job such as pay packages, responsibility and select only qualified employees (Hashim, 2009). Therefore, the following hypothesis is suggested:

Hypothesis 2: Islamic recruitment and selection practices enhance employees' trust in organization.

The Qur'anic standard is legible for evaluating job performance, only pious, meritorious, and competence worker should be award for their efficient job performance (Ahmad, 1995). Management should be aware that measuring performance in Islam must take into account the concept of accountability and responsibility. Islam is strictly prohibited nepotism and favoritism at workplace. Hence, it is proposed that:

Hypothesis 3: Presence of Islamic performance appraisal system would positively influence employees' trust in organization.

Training is the regular process of developing qualities and skills of employees' that will enable them to more productive and contributed to accomplish organizational goals (Azmi, 2008). Islamic training and development focuses on instilling Islamic values, understanding the philosophies of Allah, the concept of working as a vicegerent, a team, and a way to succeed (al-falah). Islamic training and development also stress on the importance of knowledge, 
physical and mental development, and the trainers themselves. Organizations with the belief that training can confidently reinforce performance has boost in their trust in organization. It is, thus proposed that:

Hypothesis 4: Effective training and development program would positively reinforce to enlarge employee trust in organization.

Holy Prophet Mohammad (p.b.u.h) emphasizing on human relations in working environment He said: "Allah says that I will act as a plaintiff, on the Day of Judgment against the person who engages some worker on work and takes full work from him but does not give him (full) wages." Prophet also mentioned that: "three kinds of people shall get double rewards; one of them is the worker, who is discharging his responsibilities towards his master and serving Allah well." Indeed, Islamic reward system emphasis that employees work for competitive compensation package. The trust towards organization is affected if the compensation package is not fair and timely. Consequently, this study proposed that:

Hypothesis 5: Islamic reward and compensation practices would positively extend employees' trust in organization.

\section{Data collection}

Using a structured questionnaire data were collected from the employees of seven Islamic banks in Bangladesh. Self-administered process was employed during the data collection period. The questionnaire consists of three types of questions. First of all, the questions on employee perceptions regarding Islamic HRM practices. Secondly, question on trust in organization followed by a set of demographic questions. The respondents for this were chosen purposively among the employees of Islamic banks. Mix experience and professional achievement were considered to accomplish our study. However, this study is concern regarding having time limitation of the bankers as respondent, purposive sampling is adequate for this research. A total of 236 usable responses were obtained.

Table 1 presents that around $49 \%$ of the respondents is from the two largest Islamic Banks in Bangladesh, Islami Bank Bangladesh Limited and Al-Arafa Islami Bank Limited. Out of 236 respondents around $85 \%$ were male, and around $75 \%$ of the respondents were in between the age range of $26-40$ years. About $84 \%$ of the respondents completed their post graduate degrees. The highest about $51 \%$ respondents are from officer/senior offices in position followed by the second highest $35 \%$ from the mid level executives. The percentage of respondents working for the organization up to five years was $53 \%$ whereas the same for ten years was 33\% approximately. On the average, the respondents are highly educated and experienced in their organization. 


\begin{tabular}{|c|c|c|}
\hline Name of the Organization & Frequency & Percent \\
\hline Islami Bank Bangladesh Limited (IBBL) & 57 & 24.2 \\
\hline Al-Arafah Islami Bank Limited (AIBL) & 58 & 24.6 \\
\hline Shahjalal Islamic Bank Limited & 29 & 12.3 \\
\hline First Security Islami Bank Limited & 15 & 6.4 \\
\hline Social Islami Bank Limited & 21 & 8.9 \\
\hline ICB Islami Bank Limited & 22 & 9.3 \\
\hline Exim Bank Limited & 34 & 14.4 \\
\hline Gender & Frequency & Percent \\
\hline Male & 201 & 85.2 \\
\hline Female & 35 & 14.8 \\
\hline Age & Frequency & Percent \\
\hline 26 to 30 & 76 & 32.2 \\
\hline 31 to 35 & 71 & 30.1 \\
\hline 36 to 40 & 30 & 12.7 \\
\hline 41 to 45 & 16 & 6.8 \\
\hline 46 to 50 & 13 & 5.5 \\
\hline 51 to 55 & 16 & 6.8 \\
\hline 56 and above & 14 & 5.9 \\
\hline Highest Level of Education & Frequency & Percent \\
\hline Graduate & 37 & 15.7 \\
\hline Post Graduate & 198 & 83.9 \\
\hline Others & 1 & .4 \\
\hline Position/ Designation & Frequency & Percent \\
\hline Officer/ Senior Officer & 120 & 50.8 \\
\hline Mid-level Executive (PO/SPO/SAVP) & 83 & 35.2 \\
\hline Senior Executive (VP \& above) & 33 & 14.0 \\
\hline Years of Experience in the Organization & Frequency & Percent \\
\hline Up to 5 Years & 124 & 52.5 \\
\hline Six to 10 Years & 78 & 33.1 \\
\hline More than 10 Years & 34 & 14.4 \\
\hline
\end{tabular}

Table 1. Sample Characteristics

\section{Measures}

The dependent variable for this study was measured base on the research on employee trust based on trust in supervisor, trust in coworker, and trust in organization. Twelve items construct of trust was measured with scale from Ferres and Travaglione (2003). The items were modified for Islamic HRM perspective.

The items on independent variables (i.e. knowledge, understanding, and practices of Islamic principles, recruitment and selection, performance appraisal, training and development, and reward and compensation system) developed from the study of Hashim (2009). Again all items were modified to suit for this research. All questions used a seven-point Likert scale (1 indicated "never" to 7 indicated "all the times"). 


\section{Test of reliability, validity and identification of factors}

The test of reliability measures the consistency of the variables (Nunnally, 1978). Reliability in internal consistency is most commonly used psychometric measured by assessing survey instrument and scales. Cronbach alpha is the basic method for measuring the reliability of internal consistency. Indeed, the high reliability coefficient indicates high internal consistency. This study measure the reliability by testing the coefficient alpha of the key variables (Rust \& Golombok, 1989; Nunnally, 1978).

Validity refers to the extent to which the indicators accurately measure what they are supposed to measure (Hair, Black, Babin \& Anderson, 2010). To construct validity, content validity, face validity, and convergent validity is good to estimate the degree to which the key research variables are related to each other. The concept of content validity takes on special importance where invoked to justify use of a test among the key research variables. Content validity refers two things such as; (a) the adequacy with which a specific domain of content has been samples; and (b) whether instrument is truly a comprehensive measure of area under study (Nunnally, 1978). Since the study prepared the questionnaire based on extensive literature survey and opinions of experts in the 'Shariah' law and hence, it demonstrates content validity.

According to Charles (1969) in psychological aspects to construct validity a convergent validity test refers the concepts and measurements that are supposed to be related. Convergent validity is employed as evidence for correlated between the key variables and theoretical relation (Tabachnick \& Fidell, 2007). Construct validity demonstrate the extent to which the items in a scale measure the same construct. Exploratory factor analysis was used in order to identify underlying constructs and investigate the relationships between key research variables.

\section{Results}

A varimax rotation with Kaiser-Mayer Olkin (KMO) measure of sampling adequacy was computed to determine the suitability of using factor analytical procedure. A number steps was used to finalize the factors. The factors with eigen value 1.0 only have been retained. Factors with less than 1.0 eigen value were considered insignificant and droped from this research. A total of five factors with eigenvalues greater than 1.0 were identified. Considering five conditions for trust considered in this study, the combined results of factor analysis indicates that all items loaded properly on their expected factors. Principal component analysis with Varimax rotation was used to get the rotated component matrix. Varimax rotation was used to conceptualize and simplifying the factor matrix. The result of factor analysis is shown in Table 2. 


\begin{tabular}{|c|c|c|c|c|c|}
\hline \multicolumn{6}{|c|}{ Rotated Component Matrix } \\
\hline $\begin{array}{l}\text { Variables [My organization practices, } \\
\text { considers, feels, believes...] }\end{array}$ & 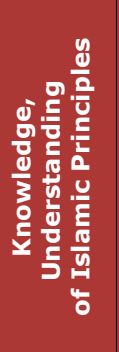 & 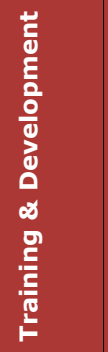 & 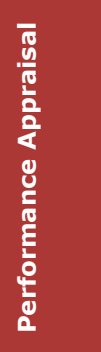 & 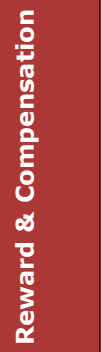 & 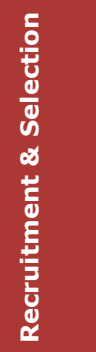 \\
\hline A good Muslim will be a good employee & .830 & -.095 & .049 & .059 & .070 \\
\hline $\begin{array}{l}\text { Islamic practices such as prayers } \& \text { fasting by the candidates is } \\
\text { very important }\end{array}$ & .819 & .129 & .109 & .021 & .156 \\
\hline Aware of Islamic requirement in paying salary to employees & .712 & .150 & -.053 & .233 & -.283 \\
\hline $\begin{array}{l}\text { Islamic understanding an important criterion in selecting the } \\
\text { candidates }\end{array}$ & .661 & .014 & .204 & .168 & .450 \\
\hline $\begin{array}{l}\text { Candidates will be asked questions pertaining to Islamic } \\
\text { understanding in the interview }\end{array}$ & .658 & -.050 & .204 & .059 & .199 \\
\hline Conducts Islamic training programs for employees regularly & .620 & .364 & .158 & .066 & .006 \\
\hline Uses Islamic criteria in selection & .614 & -.048 & .261 & .276 & .391 \\
\hline Training regularly in this organization & .016 & .817 & .102 & .028 & .072 \\
\hline Promotes training seriously & -.002 & .813 & .072 & .002 & .191 \\
\hline It is employer's responsibility to pay employees' salary on time & .068 & .769 & .140 & .125 & -.106 \\
\hline Encourages employees to seek knowledge & .137 & .744 & .220 & -.007 & .159 \\
\hline Emphasizes on improving one's performance & .131 & .667 & .350 & .078 & .076 \\
\hline Assesses the candidate's competency and interest & -.063 & .529 & .263 & .193 & .462 \\
\hline Fair performance assessment for all employees & .166 & .220 & .782 & .156 & .175 \\
\hline Measures the employees' performance regularly & .304 & .146 & .770 & .051 & .038 \\
\hline Doesn't practice any favoritism in evaluating performance & .076 & .239 & .763 & .115 & .107 \\
\hline Justice \& fairness in assessing employees' performance & -.064 & .489 & .568 & .220 & .119 \\
\hline Reward employees based on their performance & .288 & .276 & .497 & .369 & .079 \\
\hline Gives enough compensation for additional work & .114 & .028 & .071 & .861 & .093 \\
\hline Compensation policy for the employees is rational & .151 & .027 & .088 & .819 & .128 \\
\hline Enough compensation to the employees on retirement & .119 & .162 & .292 & .634 & .027 \\
\hline Selects candidates who are competent and honest & .101 & .168 & .120 & .054 & .742 \\
\hline Islamic approach in recruit \& select the potential candidates & .387 & .168 & .074 & .160 & .701 \\
\hline
\end{tabular}

Principal Component Analysis with Varimax Rotation. KMO $=0.866$ (Sig- 0.000)

Table 2. Results of Factor Analysis

Table 3 provides the reliability, and other descriptive statistics. Respondents of this study were given highest important to training and development and recruitment and selection variables. On the other hand highest variance explained by knowledge, understanding and practices of Islamic principles (32.474\%). Training and development explained $14.162 \%$ variance, performance appraisal explained $7.560 \%$ variance, reward and compensation explained $5.746 \%$ variance, recruitment and selection explained $5.494 \%$ variance. All the factors shows significant in reliability test. The statistics is checked using the Cronbach Alpha, as all the alphas are greater than 0.7 suggested by Nunnally (1978). 


\begin{tabular}{|l|c|c|c|}
\hline \multicolumn{1}{|c|}{ Factors } & Mean & Variance Explained (\%) & Cronbach Alpha \\
\hline Knowledge, Understanding \& Practices of Islamic Principles & 5.20 & 32.474 & 0.889 \\
\hline Training \& Development & 5.85 & 14.162 & 0.852 \\
\hline Performance Appraisal & 5.71 & 7.560 & 0.835 \\
\hline Reward \& Compensation & 5.20 & 5.746 & 0.782 \\
\hline Recruitment \& Selection & 5.80 & 5.494 & 0.842 \\
\hline Trust in Organization & 5.35 & & 0.850 \\
\hline
\end{tabular}

${ }^{1}$ Variance Explained $($ Total $=65.435 \%)$

Table 3. Reliability, Mean and variance Explained

Table 4 shows the results of regression analysis of five independent factors with trust in organization as dependent variable. The R Square is 0.525 , which is considered to be adequate for the study. Except performance appraisal all other factors are significant at $5 \%$ confidence level. The factor ranking according to standardized beta coefficient training and development has the highest influence in explaining trust in organization (Beta $=0.398$ ). Reward and compensation carries the second highest weight of Beta 0. 245. Knowledge, understanding, and practices of Islamic principles is the third influential factor (Beta $=0.203$ ), followed by recruitment and selection (Beta $=0.168$ ). The statistical results can summarize that from the Mean score in Table 3 and standardized beta coefficient in Table 4, trust in organization (dependent variable) is influenced the most by training and development factor matrix.

\begin{tabular}{|l|c|c|c|c|c|}
\hline \multicolumn{1}{|c|}{ Factors } & $\begin{array}{c}\text { Unstand. } \\
\text { Coefficients }\end{array}$ & \multicolumn{1}{c|}{$\begin{array}{c}\text { Stand. } \\
\text { Coefficients }\end{array}$} & t & Sig. \\
\cline { 2 - 6 } & $\mathbf{B}$ & Std. Error & Beta & & \\
\cline { 1 - 5 } $\begin{array}{l}\text { Knowledge, Understanding \& Practices of } \\
\text { Islamic Principles }\end{array}$ & .194 & .056 & .203 & 3.456 & .001 \\
\hline Training \& Development & .480 & .068 & .398 & 7.084 & .000 \\
\hline Reward \& Compensation & .244 & .054 & .245 & 4.516 & .000 \\
\hline Recruitment \& Selection & .228 & .085 & .168 & 2.683 & .008 \\
\hline Performance Appraisal & -.096 & .081 & -.067 & -1.181 & .239 \\
\hline
\end{tabular}

R Square $=0.525$, Adj. R Square $=0.514, F(5,117)=50.764$

Dependent variable $=$ Trust in Organization

Constant was not significant and was not shown in the regression output

Table 4. Regression Results

\section{Discussions and recommendations}

This paper investigates that to which extent Islamic HRM practices inspire and relevant toward revival employees' trust in organization based on Islamic principles. Additionally, explores the relationships between Islamic HRM practices and trust in organization. A total 236 employees were chosen from seven Islamic banks' branches and head office located in Dhaka city in Bangladesh. The findings illustrates that five factors such as understanding, knowledge, and practices of Islamic principles, training and development, performance appraisal, reward and compensation, and recruitment and selection system are correlated to employee trust in organization. 
This study combined five Islamic HRM practices into one regression model to examine the overall effect on employee trust in organization. The result demonstrates that all the study hypothesized except performance appraisal is significant at $5 \%$ confidence level. Consequently, the regression result support hypothesis 1 , and consistent with study, indicating that the Holy Qur'an and Hadith are source of sound and qualitative values, moral standards, concepts and fundamental guides for good and strong harmonious between human beings and organization without discrimination. Therefore, knowledge, understanding, \& practices of Islamic HRM principles positively enlighten employee trust in organization (Seidu, 2006). H2 proposes that recruitment and selection process can enhance trust in organization. The result support this proposition and consistent with literature that the Shariah law strictly prohibited favoritism and nepotism, and select merit and competence candidate only with full trustworthiness in recruitment and selection process, which directly influence employees' to enhance their trust in management and organization (Ali, Gibbs \& Camp, 2000).

Effective training and development positively reinforce to enlarge trust in organization. $\mathrm{H} 4$ pass in regression test and consist with previous literature that the Islamic worker and the Islamic movement obliged themselves to seek for knowledge, to do the right things, do them well, and ensure their trust toward organization (Altalib, 1991). Qur'anic standard is eligible in employees' reward and compensation system. The study result accepts $\mathrm{H} 5$ and shows positive significant relationship between trust in organization, and reward \& compensation system. Islam gives proper recognition to the dignity of work and employment through adequate reward and compensation system (Ali, 2005). Incase of $\mathrm{H} 3$ the regression result shows that there is no or negative significant relationship between performance appraisal and trust in organization. However, although conceptually literature has support on it but empirically have no enough evidence. Therefore, the study suggest for future empirical study on the relationship between Islamic performance appraisal and trust in organization (Hashim, 2009).

\section{Limitations and future directions}

The study has some limitations like other empirical studies particularly, in sample size because insufficient sample size restricts the generalization of the findings. While future research of this field can more strengthen by increasing the sample size and, emphases on different Islamic institutions as their study field. In addition, can evaluate or attempt to discover the relationship between Islamic HRM practices with other relevant factors such as performance appraisal, employee participation, communication and information sharing, and others organizational outcomes factors such as job satisfaction, commitment, and organizational performance. 


\section{Implications of the study}

This study explains 65 percent of the variance in Trust in organization. Indeed, as there is no benchmark found from previous studies, this study provides strong empirical evidence on the ground of relationships between Islamic HRM practices and Trust in organization as an introductory research. Moreover, the present study contributes in both implications for researchers and practitioners.

This research can serve as a starting point for other future researchers by further exploring on the relationships between Islamic HRM practices and Trust in organization, in different study field in the context of national or cross-national differences. Additionally, future research needs to focus on a large cross sectional analysis by using more diversified random samples to verify the findings of the present study. More so, for further inquiries future study could also examine the causal relationships between Islamic HRM practices and Trust in organization by employing a structural equation modeling technique analysis.

On the other hand, the study presents a clear image on the relationships between Islamic HRM practices and Trust in organization. Mostly, the study helps to create better awareness for the HR managers to identify the core problematic employee related issues, and take necessary actions to rectify them. Furthermore, this study aids for the professional managerial consultant, practitioners, and non-professional Islamic profound philosophers' who advice for comply 'Shariah' principles to obtain sufficient information and strong evidence for the particular aspects of Islamic HRM practices in various organizational atmospheres.

\section{Conclusion}

The purpose of the study is to investigate to which extent Islamic human resource management practices inspire and relevant toward revival employees trust in organization. In addition, explore and identify the relationships between Islamic HRM practices and Trust in organization. Principally, the research was done under theoretical framework that was grounded on the previous literature review. In addition, the result of multiple regression analysis reports that knowledge, understanding and practices of Islamic principles; recruitment and selection; training and development; and reward and compensation are significant elements of trust in organization. The model explains 65 percent of the variance which strongly suggest for the positive relationships between Islamic HRM practices and Trust in organization in work environment. Consequently, the research have suggests that employee trust in organization is very much relevant in Islamic HRM practices to accomplish organizational goals.

HR functions are vital for both Islamic and non Islamic HRM practices. Principally, it is obligatory for Muslims and Islamic institutions to accept and obey Islamic rules, regulation and guidelines as a way of life rather than a separate activity particularly, to run the organization under Islamic law. Additionally, for non Islamic institutions they can practices Islamic values to 
accomplish the advantages of Islamic code. Indeed, this study has significance contributions in HRM discipline as it shrinks the knowledge gap by presenting empirical evidence in this field. Furthermore, the study suggests and recommends for knowledge, understanding, and practices of Islamic principles should be embedding as a mandatory practice of HRM to oblige 'Shariah' or Islamic law.

\section{References}

Abbasi, A.S., Rehman, K., \& Abbasi, S.H. (2010). Welfare and protection model for organizational management: The Islamic perspective. African Journal of Business Management, 4, 739-747.

Ahmad, M. (1995). Business Ethics in Islam. International Institute of Islamic Thought, Islamabad.

Al-Faruqi, I.R., \& Al-Bann, G. (1980). Towards Islamic labour and unionism. International Islamic Confederation of Labour.

Ali, A. (2005). Islamic Perspectives on Management and Organization. Cheltenham, Northampton, MA: Edward Elgar.

Ali, A., Gibbs, M., \& Camp, R. (2000). Human resources strategy: the Ten Commandments perspective. Int. Journal of Sociology and Social Policy, 20, 114-132. http://dx.doi.org/10.1108/01443330010789205

Altalib, H. (1991). Training guide for Islamic workers. International Institute of Islamic Thought, Herndon, VA.

Asad, M. (2007). The Message of The Quran. Source: http://www.usc.edu/schools/college/crcc/private/cmje/religious text/The Message of The Q uran_by_Muhammad_Asad.pdf.

Azmi, I.A.G. (2008). Islamic Human Resource Practices and Organizational Performance: A Study on Malaysian Islamic Organizations. Academy of Islamic Studies, UM.

Beekun, R. (1997). Islamic business ethics. International Institute of Islamic Thought. Herndon, Va.

Carnevale, D.G., \& Wechsler, B. (1992). Trust in the public sector: individual and organizational determinants. Administration and Society, 23, 471-494. http://dx.doi.org/10.1177/009539979202300404

Charles, A.P. (1969). Convergent and discriminant validation of measures of personel needs. Journal of Educational Measurement, 6(2), 103-107. http://dx.doi.org/10.1111/j.17453984.1969.tb00666.x 
Cook, K.S., Cheshire, C., \& Gerbasi, A. (2006). Power, dependence and social exchange. Stanford University Press.

Dirks, K.T., \& Ferrin, D.L. (2001). The Role of Trust in Organizational Settings: Organization Science. Journal of the Institute of Management Sciences, 12, 450-467.

Ferres, N., \& Travaglione, T. (2003). The development and validation of the Workplace Trust Survey (WTS): Combining quantitative and qualitative methodologies. Paper presented at Development and Validation of the WTS, APROS Mexico.

Fiorina, C. (2001). Technology, business and our way of life: what's next. September 26, 2001. Hewlett-Packard Development Company, L.P.

Flippo, E.B. (1984). Personnel Management. Six Edition. New York: McGraw Hill Book Co.

Hair, J.F., Black, W.C., Babin, B.J., \& Anderson, R.E. (2010). Multivariate data analysis. A global perspective. Seventh edition. Pearson.

Hunt, M., Lara, T.M., \& Hughey, A.W. (2009). Establishing and maintaining organizational trust in the 21st century. Industry of Higher Education, 23, 71-77. http://dx.doi.org/10.5367/000000009788146584

Hashim, J. (2008). The Quran-Based Human Resource Management and its Eddects on Organizational Justice, Job Satisfaction and Turnover Intention. The Journal of International Management Studies, 3, 148-159.

Hashim, J. (2009). Islamic revival in human resource management practices among selected Islamic organizations in Malaysia. International Journal of Islamic and Middle Eastern Finance and Management, 2, 251-267. http://dx.doi.org/10.1108/17538390910986362

Khan, B., Farooq, A., \& Hussain, Z. (2010). Human resource management: an Islamic perspective. Asia-Pacific Journal of Business Administration, 2, 17-34. http://dx.doi.org/10.1108/17574321011037558

Lee, F.H., \& Lee, F.Z. (2007). The relationships between HRM practices, leadership style, competitive strategy and business performance in Taiwanese steel industry. International Journal of Human Resource Management, 21, 1351-1372. http://dx.doi.org/10.1080/09585192.2010.488428

Mishra, J., \& Morrissey, M.A. (1990). Trust in employee/employer relationships: A survey of West Michigan managers. Public Personnel Management, 19, 443-485.

Namazie, P., \& Frame, P. (2007). Developments in human resource management in Iran. Int. Journal of Human Resource Management, 18, 159-171. http://dx.doi.org/10.1080/09585190601068573 
Nunnally, J.C. (1978). Psychometric theory. New York, NY: McGrew-Hill.

Perry, R.W. (2004). The relationship of affective organizational commitment with supervisory trust. Review of Public Personnel Administration, 24, 133-149. http://dx.doi.org/10.1177/0734371X03262452

Pfeffer, J. (2005). Producing sustainable competitive advantage through the effective management of people. Academy of Management Executive, 19, 95-106. http://dx.doi.org/10.5465/AME.2005.19417910

Pucetaite, R., Lamsa, A.M., \& Novelskaite, A. (2010). Building organizational trust in a low trust societal context. Baltic Journal of Management, 5, 197-217. http://dx.doi.org/10.1108/17465261011045124

Rust, J., \& Golombok, S. (1989). Modern psychometrics. London: Routledge.

Seidu, A.M. (2006). Islamic Concept of Employer-Employee Relationships. Islamic Economics Research Centre. King Abdul Aziz University, Jeddad, Saudi Arabia.

Shaw, J.D., Delery, J.E., \& Abdullah M.H.A. (2003). Organizational commitment and performance among gust workers and citizens of an Arab country. Journal of Business Research, 56, 1021-1030. http://dx.doi.org/10.1016/S0148-2963(01)00316-2

Storey, J.(ed). (1995). Human resource management: A critical text. London: Routledge.

Syed Agil, S.O.b, Jasin, D., \& Pa'wan, F. (2007). Nine Islamic Management Practices and Habits in Islamic History: Lessons for Managers and Leaders. Unitar E-Journal, 3, 42-59.

Tabachnick, B.G., \& Fidell, L.S. (2007). Using multivariate statistics. Fifth edition, New York.

Tayeb, M. (1997). Islamic revival in Asia and human resource management. Employee Relation, 19, 352-364. http://dx.doi.org/10.1108/01425459710170086

Whitener, E.M. (1997). The impact of human resource activities on employee trust. Human Resource Management Review, 7, 389-404. http://dx.doi.org/10.1016/S1053-4822(97)90026-7

Whitener, E.M. (2001). Do "high commitment" human resource practice affect employee commitment? A cross level analysis using hierarchical linear modeling. Journal of Management, 27, 515-535.

Williams, C.C. (2005). Trust diffusion: The effect of Interpersonal trust on structure, function, and organizational transparency. Business Society, 44, 357-368. http://dx.doi.org/10.1177/0007650305275299 
Yousef, D. (2001). Islamic work ethic - a moderator between organizational commitment and job satisfaction in a cross-cultural context. Pak. Personnel Review, 30, 152-169. http://dx.doi.org/10.1108/00483480110380325

Zeffane, R., \& Connell, J. (2003). Trust and HRM in the new millennium. Int. Journal of Human Resource Management, 14, 3-11. http://dx.doi.org/10.1080/09585190210158484

Journal of Industrial Engineering and Management, 2013 (www.jiem.org)

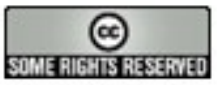

Article's contents are provided on a Attribution-Non Commercial 3.0 Creative commons license. Readers are allowed to copy, distribute and communicate article's contents, provided the author's and Journal of Industrial Engineering and Management's names are included. It must not be used for commercial purposes. To see the complete license contents, please visit http://creativecommons.org/licenses/by-nc/3.0/. 